\title{
Reference genes for mesangial cell and podocyte qPCR gene expression studies under high-glucose and renin-angiotensin-system blocker conditions
}

Nicole Dittrich Hosni ${ }^{1}$, Ana Carolina Anauate ${ }^{1}$, Mirian Aparecida Boim ${ }^{1}$

(1) Nephrology Division, Department of Medicine, Universidade Federal de São Paulo, São Paulo, Brazil.

\section{Corresponding author:}

Mirian Aparecida Boim, $\mathrm{PhD}$

Nephrology Division

Universidade Federal de São Paulo

Rua Botucatu 740 - Vila Clementino

04023-900

São Paulo - Brazil

Tel $+5511-55764848$ ext 2465

Fax $+5511-59041684$

E-mail address: maboim@unifesp.br

Running title: qPCR reference genes for mesangial cells and podocytes.

Key Words: Essential genes, Diabetic Nephropathy, Mesangial Cells, Podocytes, Real-Time Polymerase Chain Reaction, Renin-Angiotensin System, In Vitro Techniques. 


\section{ABSTRACT}

Background: Real-time PCR remains currently the gold standard method for gene expression studies. Identification of the best reference gene is a key point in performing high quality qPCR, providing strong support for results, as well as performing as a source of bias when inappropriately chosen. Mesangial cells and podocytes, as essential cell lines to study diabetic kidney disease (DKD) physiopathology, demand accurate analysis of the reference genes used so far to enhance validity of gene expression studies, especially regarding high glucose (HG) and DKD treatments, with angiotensin II receptor blockers (e.g. Losartan) being the most commonly used. This study aimed to evaluate the suitability and define the most stable reference gene for mesangial cells and podocytes studies of an in vitro DKD model of disease and its treatment.

Methods: Five software packages (RefFinder, NormFinder, GeNorm, Bestkeeper, and DataAssist) and the comparative $\Delta \mathrm{Ct}$ method were selected to analyze six different candidate genes: HPRT, ACTB, PGAM-1, GAPDH, PPIA, and B2M. RNA was extracted and cDNA was synthesized from immortalized mouse mesangial cells and podocytes cultured in 4 groups: control $(\mathrm{n}=5 ; 5 \mathrm{mM}$ glucose), mannitol $(\mathrm{n}=5 ; 30 \mathrm{mM}$, as osmotic control), $\mathrm{HG}(\mathrm{n}=5 ; 30 \mathrm{mM}$ glucose), and $\mathrm{HG}+$ losartan ( $\mathrm{n}=5 ; 30 \mathrm{mM}$ glucose and $10^{-4} \mathrm{mM}$ of losartan). Real-time PCR was performed according to MIQE guidelines.

Results: We identified that the use of 2 genes is the best combination for qPCR normalization for both mesangial cell and podocytes. For mesangial cells, the combination of HPRT and $A C T B$ presented higher stability values. For podocytes, HPRT and GAPDH showed the best results.

Conclusion: This analysis provides support for the use of $H P R T$ and $A C T B$ as reference genes in mouse mesangial cell studies of gene expression via real-time PCR technique, while for podocytes, HPRT and GAPDH should be chosen.

\section{INTRODUCTION}

Globally, diabetic kidney disease (DKD) related deaths are increasing compared to other types of chronic kidney diseases (1). Diabetes endures as the dominant cause of end-stage renal disease, being responsible for approximately half of cases in developed countries (2).

DKD development triggers glomerular injuries, including hyperfiltration, progressive albuminuria, declining glomerular filtration rate, and eventually end-stage renal disease (3). 
Additionally, early cellular damage appears in mesangial cells and podocytes (4). Characteristic features of mesangial damage relies on mesangial expansion, following cell enlargement, secretion of extracellular matrix, and ultimately nodular glomerulosclerosis (5). Commonly, podocytes exposed to a high glucose environment develop foot process effacement, hypertrophy, detachment from the basal membrane, and apoptosis $(6,7)$.

Analysis of gene expressions in vivo and in vitro models of DKD are among the strategies that contribute to better understand the pathophysiological mechanisms of progression of DKD. The very sensitive quantitative real-time PCR (qPCR) is currently the gold standard method to evaluate gene expression (8). Identification of the best reference gene stands as a key point in performing high-quality qPCR, providing strong support for results, as well as acting as a source of bias when inappropriately chosen. Considering the many steps the procedure goes through (RNA extraction, reverse-transcription, amplification efficiency, etc.) and the fact that the data is most frequently relative, not absolute, normalization is established as a critical step to properly standardize the experiment and, thus, provide decisive results for a qPCR assay. Although the use of reference genes is absolutely acknowledged as the most correct method of normalization, gene choice must be validated according to tissue, cell type, experimental design, and conditions (9). There must be a detailed report of the method used to select the most stable gene and the optimal number of genes recommended (10). Specific celltypes from glomeruli, however, do not have support from the literature concerning the best normalization gene for qPCR studies, circumstance that may complicate the interpretation of qPCR data for researchers on the field, misrepresenting the results' reliability.

Mesangial cells and podocytes, as essential cell lines in DKD, demand accurate analysis of the most excellent reference genes to enhance validity of gene expression studies in the field, especially regarding high glucose (HG) and different treatments, being angiotensin II receptor blockers the most frequently used $(11,12)$. Unfortunately, to our knowledge, the only available reference in the literature regarding DKD qPCR reference genes relies on entire glomerulus analysis, not suitable to cell specific in vitro assays (13).

Our goal was to evaluate the suitability and define the most stable reference gene specifically for mesangial cell and podocyte studies of an in vitro DKD model of disease and its treatment, among six commonly used reference genes (HPRT, ACTB, PGAM-1, GAPDH, $P P I A$, and $B 2 M)$.

\section{MATERIALS AND METHODS}




\section{Cell lines and cell culture}

Immortalized mesangial cells (SV40 MES 13, ATCC) were cultured in DMEM (Invitrogen Corporation, Gaithersburg, MD, USA) containing 10\% fetal bovine serum (FBS), penicillin $(50 \mathrm{U} / \mathrm{ml})$ and $2.6 \mathrm{~g}$ HEPES at $37^{\circ} \mathrm{C}$. Podocytes (Cell line E11, CLS) were cultured in RPMI 1640 medium (Invitrogen Corporation, Gaithersburg, MD, USA) supplemented with $10 \%$ fetal bovine serum and interferon-gama (INF-gama) at $33{ }^{\circ} \mathrm{C}$; after achieving the desired confluence, flasks were transferred to a $37{ }^{\circ} \mathrm{C}$ incubator for the differentiation process for 14 days without $I N F$-gama. Both cell types were cultured until $>90 \%$ of confluence and remained in a $5 \% \mathrm{CO}_{2}$ environment. After 24 hours in $1 \% \mathrm{FBS}$, each group received the designated stimulus for 24 hours: pure medium (control group), medium containing $30 \mathrm{mM}$ mannitol (as osmotic control, mannitol group), or 30mM D-glucose (high-glucose group) or 30mM Dglucose combined with 100uM losartan (losartan group). The study workflow is shown in Figure 1.

\section{RNA extraction, quality parameters and reverse transcription}

Total RNA was extracted using TRIzol reagent (Life Technologies, USA), according to the manufacturer's instructions. RNA concentration and quality $(260 / 280$ ratio $>1.8$ and 260/230 ratio 2.0-2.2, indicating high purity) was assessed using the NanoVue spectrophotometer (GE Healthcare Life Sciences, USA). RNA integrity was also analyzed by gel electrophoresis. After RNA extraction, we performed DNAse treatment to avoid genomic DNA contamination. An amount of $2 \mu \mathrm{g}$ of total RNA was reverse-transcribed into cDNA (High Capacity cDNA Reverse Transcription Kit, Applied Biosystems, USA). The reaction mixture was incubated for 10 minutes at $25^{\circ} \mathrm{C}, 120$ minutes at $37{ }^{\circ} \mathrm{C}$ and 5 seconds at $85{ }^{\circ} \mathrm{C}$.

\section{qPCR performance}

Gene expression analysis was performed by qPCR using SYBR Green (Applied Biosystems) in QuantStudio 7 Flex (Applied Biosystems), in accordance with the manufacturer's instructions. Primer sequences for the six genes used are exposed in Table 1. Melting curves of all primers are exposed in Figure 2. All samples were evaluated in triplicate. 
Table 1. Primer sequences for the six candidate genes.

\begin{tabular}{lllll}
\hline $\begin{array}{l}\text { Gene } \\
\text { symbol }\end{array}$ & Target gene & Accession ID & Primer sequence (5'-3') & $\begin{array}{c}\text { Amplicon } \\
\text { length (bp) }\end{array}$ \\
\hline$A C T B$ & Beta actin & NM_007393.5 & $\begin{array}{l}\text { CGCAGCCACTGTCGAGT } \\
\text { GTCATCCATGGCGAACTGGT }\end{array}$ & 96 \\
GAPDH & $\begin{array}{l}\text { Glyceraldehyde-3- } \\
\text { phosphate dehydrogenase }\end{array}$ & NM_001357943 & $\begin{array}{l}\text { GGTGGTCTCCTCTGACTTCAACA } \\
\text { ACCAGGAAATGAGCTTGACAAAG }\end{array}$ & 101 \\
B2M & Beta-2 microglobulin & NM_009735.3 & $\begin{array}{l}\text { ATACGCCTGCAGAGTTAAGC } \\
\text { TCACATGTCTCGATCCCAGT }\end{array}$ & 70 \\
& Peptidylprolyl isomerase A & NM_008907.2 & $\begin{array}{l}\text { CAGGTCCATCTACGGAGAGA } \\
\text { CATCCAGCCATTCAGTCTTG }\end{array}$ & 146 \\
HPRT & $\begin{array}{l}\text { Hypoxanthine } \\
\text { phosphoribosyltransferase }\end{array}$ & NM_013556.2 & $\begin{array}{l}\text { CTCATGGACTGATTATGGACAGGAC } \\
\text { GCAGGTCAGCAAAGAACTTATAGCC }\end{array}$ & 123 \\
$P G A M-1$ & Phosphoglycerate mutase 1 & NM_023418.2 & $\begin{array}{l}\text { ATCAGCAAGGATCGCAGGTA } \\
\text { TTCATTCCAGAAGGGCAGTG }\end{array}$ & 102 \\
\hline
\end{tabular}

\section{Software analysis for stability of candidate reference genes}

To establish the best reference gene and best combination, we evaluated qPCR results in five different software applications: RefFinder, NormFinder, GeNorm, Bestkeeper, and DataAssist. We also evaluated the data with the comparative $\Delta \mathrm{Ct}$ method.

NormFinder is a freely available tool that provides the stability value for several candidate genes tested on a sample set. Any required number of samples are subject to the analysis, providing an estimation of expression variation (14). GeNorm software works as an algorithm (M value) to determine the most stable reference genes among a collection of tested candidate genes. The tool calculates a normalization factor for each sample, established according to the geometric mean of the reference genes number (10). Bestkeeper is an excel based spreadsheet software that determines the best suited reference genes and combines them into an index, allowing a comparison with further target genes to decide which of them has the best suitability for normalization. The application acknowledges extremely deviating samples, that can be removed from the calculation and improve the results reliability (15). DataAssist is an Applied Biosystems' software that quantifies relative gene expression across a given number of samples. It provides an "Endogenous Control Selection" tool that shows the Ct values of candidate genes for all samples as well as a score (16). The $\Delta \mathrm{Ct}$ method compares the relative expression values between 'pairs of genes', implementing an elimination process 
according to a ranking of the variability among each pair. Subsequently, the most appropriate gene of reference can be selected (17).

The program GenEx was used in order to calculate the accumulated standard deviation across the samples, providing the necessary number of genes required for the minimum standard deviation (18). Finally, we used the RefFinder software, an all-encompassing program developed with the aim to evaluate reference genes from experimental data. The tool includes available software algorithms and methods, all of them previously mentioned: geNorm, Normfinder, BestKeeper, and the comparative $\Delta \mathrm{Ct}$ method. Supported by the ranking of each program, the RefFinder calculates the geometric mean for an overall final ranking (19).

\section{Statistical Analysis}

The entire dataset was analyzed regarding normality (Shapiro-Wilk test) and homogeneity (Levene's test). All comparisons were analyzed using ANOVA or KruskalWallis, according to each test prerequisites. The level of significance considered was $p<0.05$. Analysis was performed on Jamovi software, version 1.0.1. Results are expressed as mean \pm standard deviation (SD).

\section{RESULTS}

\section{Expression levels profile of candidate genes of reference}

Raw Ct values were acquired in triplicate for both mesangial cell and podocytes samples and analyzed according to each stimulus received. Ct values are inversely proportional to the gene expression. The $\mathrm{Ct}$ mean of the candidate genes ranged from 29.20 to 18.55 in mesangial cells. The highest $\mathrm{Ct}$ among the candidate genes in mesangial cells was achieved by $A C T B(29.20 \pm 1.09)$, and the lowest by PPIA (18.55 \pm 0.79$). H P R T$ showed a mean of 23.48 \pm 0.97 , followed by GAPDH (22.46 \pm 1.04$), P G A M-121.86 \pm 1.06$ and B2M $18.66 \pm 0.78$.

For podocytes, otherwise, the mean ranged from 24.45 to 13.02 . ACTB achieved the highest value (24.45 \pm 1.2$)$, while the lowest value was achieved by $B 2 M(13.02 \pm 0.51)$. The remaining candidates showed a mean between 19.19 and 14.98: GAPDH (19.19 \pm 1.00$)$ was followed by HPRT $(18.85 \pm 0.79)$, PGAM-1 $(17.90 \pm 1.16)$ and PPIA $(14.98 \pm 1.06)$. The mean $\mathrm{Ct}$ value of the triplicates according to each gene and cell line is shown in Figures 3A and 3B.

\section{Stability of candidate genes}


We applied the six algorithms described previously to determine the stability of each reference gene candidate according to the cell type. After analysis with different algorithms and a visual inspection of the ranked genes, we concluded that HPRT and ACTB for mesangial cells (Table 2) and HPRT together with GAPDH for podocytes were the best reference genes for qPCR studies (Table 3).

NormFinder showed the lowest stability value for HPRT for both mesangial cells and podocytes, determining this gene as the best reference gene according to this algorithm. As recommended by software instructions, any gene with a stability value higher than 0.5 is considered unstable - all genes tested showed a stability value lower than the cutoff.

Individual results for BestKeeper showed, for mesangial cells, the lowest coefficient of variation $(\mathrm{CV})$ for $A C T B$ thus, indicating this gene as the best for this cell type under the established conditions according to this software. For podocytes, the lowest CV was displayed for $B 2 M$, showing up as the most stable option. No candidate gene showed a SD higher than 1.0 , the fixed software threshold for instability.

The DataAssist software retrieved as the most stable gene for mesangial cells the PGAM-1 gene. Nevertheless, the lowest score for podocytes was achieved by HPRT.

Regarding the $\triangle \mathrm{Ct}$ method, the lowest SD was obtained by HPRT for both cell lines. The highest SD was shown by $B 2 M$ for mesangial cells and $A C T B$ for podocytes, classifying them as the least stable genes according to the method.

For mesangial cells, GeNorm showed the best results for $A C T B$ and GAPDH together according to M-values. $B 2 M$ was considered the least stable gene. For podocytes, the best pair of M-values was given to HPRT and GAPDH. The least stable gene for podocytes was PPIA.

Based on these results and visual inspection of all data (Table 2 and 3), HPRT was selected as the overall best reference gene for both mesangial cells and podocytes. For mesangial cells, HPRT and ACTB were considered the best combination of genes for qPCR normalization (Table 2). PPIA, otherwise, was classified as the least stable for mesangial cells. Along with $H P R T, G A P D H$ was also ranked as the most stable candidate reference gene for podocytes, while $A C T B, P G A M-1$, and PPIA were found the least feasible genes (Table 3). 
Table 2. Ranking of candidate reference genes by each method used for mesangial cells.

\begin{tabular}{|c|c|c|c|c|c|c|c|c|c|c|c|c|c|c|}
\hline NormFinder* & Stability value & GeNorm & M value & BestKeeper & $\mathrm{CV}[\% \mathrm{CP}]$ & std dev $[ \pm \mathrm{CP}]$ & DataAssist & Score & RefFinder & Geomean & $\begin{array}{c}\Delta \mathrm{Ct} \\
\text { method }\end{array}$ & $\begin{array}{l}\text { Mean } \\
\text { SD }\end{array}$ & $\begin{array}{c}\text { Visual } \\
\text { inspection** }\end{array}$ & Frequency \\
\hline$H P R T$ & 0.118 & $A C T B$ & 0.031 & $A C T B$ & 2.96 & 0.87 & $P G A M-1$ & 5.324 & $H P R T$ & 1.00 & $H P R T$ & 0.67 & $H P R T$ & $3 x$ \\
\hline$A C T B$ & 0.158 & $G A P D H$ & 0.031 & $H P R T$ & 2.99 & 0.70 & PPIA & 5.514 & $A C T B$ & 2.21 & $A C T B$ & 0.75 & $A C T B$ & $2 \mathrm{x}$ \\
\hline$G A P D H$ & 0.179 & $P G A M-1$ & 0.034 & $B 2 M$ & 3.03 & 0.57 & $H P R T$ & 5.525 & PPIA & 3.41 & $P G A M-1$ & 0.77 & $P G A M-1$ & $1 \mathrm{x}$ \\
\hline PGAM-1 & 0.181 & $H P R T$ & 0.038 & PPIA & 3.41 & 0.63 & $A C T B$ & 5.624 & $P G A M-1$ & 3.94 & PPIA & 0.77 & GAPDH & $1 x$ \\
\hline PPIA & 0.226 & PPIA & 0.039 & $G A P D H$ & 3.51 & 0.79 & $G A P D H$ & 5.907 & $G A P D H$ & 4.47 & $G A P D H$ & 0.86 & $B 2 M$ & $0 \mathrm{x}$ \\
\hline$B 2 M$ & 0.244 & $B 2 M$ & 0.042 & $P G A M-1$ & 3.65 & 0.80 & $B 2 M$ & 6.835 & $B 2 M$ & 4.56 & $B 2 M$ & 0.92 & PPIA & $0 \mathrm{x}$ \\
\hline
\end{tabular}

Lower values indicate increased stability in gene expression. Each software result is shown in order of stability.

*Best reference genes determined by NormFinder when the intra- and intergroup variations were not considered.

${ }^{* *}$ Visual inspection refers to the number of times each gene appears as the top one in each analysis 
Table 3. Ranking of candidate reference genes by each method used for podocytes.

\begin{tabular}{|c|c|c|c|c|c|c|c|c|c|c|c|c|c|c|}
\hline NormFinder* & $\begin{array}{c}\text { Stability } \\
\text { value }\end{array}$ & GeNorm & $\begin{array}{c}\text { M } \\
\text { value }\end{array}$ & BestKeeper & $\begin{array}{c}\mathrm{CV}[\% \\
\mathrm{CP}]\end{array}$ & $\begin{array}{c}\text { std dev }[ \pm \\
\text { CP] }\end{array}$ & DataAssist & Score & RefFinder & Geomean & $\begin{array}{c}\Delta \mathrm{Ct} \\
\text { method }\end{array}$ & $\begin{array}{c}\text { Mean } \\
\text { SD }\end{array}$ & $\begin{array}{c}\text { Visual } \\
\text { inspection*** }\end{array}$ & Frequency \\
\hline$H P R T$ & 0.174 & $H P R T$ & 0.030 & $B 2 M$ & 0.43 & 13.64 & $H P R T$ & 0.54 & $H P R T$ & 1.32 & $H P R T$ & 0.66 & $H P R T$ & $5 \mathrm{x}$ \\
\hline$G A P D H$ & 0.204 & GAPDH & 0.030 & $H P R T$ & 0.65 & 20.31 & $G A P D H$ & 0.56 & $G A P D H$ & 2.21 & $G A P D H$ & 0.69 & $B 2 M$ & $1 \mathrm{x}$ \\
\hline PPIA & 0.316 & $B 2 M$ & 0.037 & $G A P D H$ & 0.79 & 21.40 & $P G A M-1$ & 0.66 & PGAM-1 & 2.59 & $P G A M-1$ & 0.79 & $G A P D H$ & $1 \mathrm{x}$ \\
\hline$P G A M-1$ & 0.324 & $A C T B$ & 0.044 & $P G A M-1$ & 0.82 & 20.13 & PPIA & 0.69 & $B 2 M$ & 2.83 & $B 2 M$ & 0.88 & $P G A M-1$ & $0 \mathrm{x}$ \\
\hline$B 2 M$ & 0.349 & PGAM-1 & 0.049 & $A C T B$ & 0.87 & 26.50 & $B 2 M$ & 0.72 & PPIA & 5.23 & PPIA & 0.90 & PPIA & $0 \mathrm{x}$ \\
\hline$A C T B$ & 0.373 & PPIA & 0.053 & PPIA & 0.88 & 16.51 & $A C T B$ & 0.85 & $A C T B$ & 5.42 & $A C T B$ & 1.01 & $A C T B$ & $0 \mathrm{x}$ \\
\hline
\end{tabular}

Lower values indicate increased stability in gene expression. Each software result is shown in order of stability.

${ }^{*}$ Best reference genes determined by NormFinder when the intra- and intergroup variations were not considered.

${ }^{\star *} V$ isual inspection refers to the number of times each gene appears as the top one in each analysis. 


\section{Determination of the suitable number of reference genes}

For each cell line, we determined the optimal number of genes to be used in a gene expression experiment via qPCR. This analysis was performed by the Genex software and the accumulated standard deviation (Acc.SD) parameter was considered for each cell line according to the number of genes used. For mesangial cells, we concluded that the Acc.SD decreased proportionally to the number of genes used. We also observed that the difference from one to two genes was higher than 0.1 . However, the difference from two to three genes was smaller than 0.1 - a pattern that could be noticed in the following number of genes as well, achieving a plateau. Therefore, it would be reasonable to use two reference genes (HPRT and $A C T B)$ and maintain a smaller source of error, since a higher number of genes increases the overall noise of the experiment as well as the cost (Figure 4A).

For podocytes, the lowest Acc.SD was acquired in the presence of 2 reference genes (Figure 4B). In this case, the use of 2 genes - HPRT and GAPDH or B2M, the top genes according to the visual inspection - to analyze qPCR results would be the best option as well. Since $G A P D H$ and $B 2 M$ showed the same results on visual inspection ranking, we looked closely to the performance of each gene on all softwares: besides being the top gene for BestKeeper, B2M appeared in $5^{\text {th }}$ place for NormFinder, $3^{\text {rd }}$ for GeNorm, $5^{\text {th }}$ for DataAssist, $4^{\text {th }}$ for RefFinder and $4^{\text {th }}$ again for $\triangle \mathrm{Ct}$ method. $G A P D H$, however, in addition to being the top gene in GeNorm, appeared as $2^{\text {nd }}$ for NormFinder, $3^{\text {rd }}$ for BestKeeper, $2^{\text {nd }}$ for DataAssist, $2^{\text {nd }}$ for RefFinder and $2^{\text {nd }}$ for the $\Delta \mathrm{Ct}$ method. Considering the overall performance of both genes, $G A P D H$ was selected as a best option to pair with HPRT as reference genes for podocytes.

\section{Correlation between the top candidates}

After determining that the use of 2 reference genes would be the ideal option for mesangial cells and podocytes, we checked if the best 2 genes for each cell line were correlated and therefore could be used simultaneously. We found that the 2 recommended genes for mesangial cells, $H P R T$ and $A C T B$, were strongly correlated $(\rho=0.80, \mathrm{p}<0.0001$, Figure 5A), providing support to the recommendation of using these genes at the same time to analyze qPCR data. The same occurred for podocytes: there was a strong correlation between HPRT and $G A P D H$ expression data, again supporting the use of those genes together as reference genes for qPCR $(\rho=0.92, \mathrm{p}<0.0001$, Figure 5B).

\section{Validation of the best reference genes}


As results showed that HPRT and $A C T B$ were the best genes for normalization of mesangial cells qPCR data, we confirmed statistically that there was no difference among the four studied groups regarding the expression of these genes ( $p>0.05$ by Kruskal-Wallis test) (Figure 3A). We also confirmed that there was no difference among the groups of podocytes regarding HPRT and GAPDH expression, the best genes for this cell type (Figure 3B). In fact, there was no difference between the groups for all candidate genes, in both cell lines.

\section{DISCUSSION}

The pipeline used in this work has been extensively used throughout many laboratories and is accepted by literature as a reliable approach to determine the best reference gene to be used, specifically for qPCR in a predetermined biological sample and condition $(18,20,21)$. Here, we aimed to provide data to determine the most suitable reference gene to be used for mesangial cells and podocytes exposed to a high glucose environment and treated with Losartan, a very known in vitro model for diabetic kidney disease (7,22-25).

Many research groups have clearly shown a need for studies that approach reference genes for their specific study sample $(26,27)$. The importance of using the best-known reference gene and to pragmatically look at this question relies on the frequent inappropriate use of least feasible reference genes resulting in an inaccurate analysis of qPCR results, and therefore in loss of reagents, time, and samples. Sometimes the most known genes, such as $A C T B$ and $G A P D H$, are used for samples and conditions that do not support their use. Even in the most recent years, researchers still normalize their qPCR data of in vitro studies based on the most frequently used genes, as $A C T B$ for podocytes and $G A P D H$ for mesangial cells (opposite to the finding we had in our analysis), without literature support for this choice (2833). Unfortunately, some studies do not clearly provide which reference gene was used to normalize the data, or even if there was a data normalization. This shows the need of systematic analysis to identify the best gene or genes to be used as references.

In fact, literature frequently stands against the use of many popular reference genes. A systematic review performed on vertebrate studies found that $72 \%$ of the included studies used $G A P D H, A C T B$ or $18 S$ as normalizing genes. The same group shows that as the number of screened reference genes for a specific study design increases, the chance of one of these three genes being the most stable decreases (34).

In nephrology, few studies have addressed reference genes for qPCR normalization (13), exposing a lack of information regarding which gene must be used for gene expression studies for kidney samples and cell lines. Kidney itself is an organ specifically characterized 
by numerous cell types, justifying the need for reference genes regarding each different cell line $(35,36)$.

The genes selected as best ones for the studied samples - HPRT and ACTB for mesangial cells and HPRT along with $B 2 M$ for podocytes - are extensively described in literature. Hypoxanthine phosphoribosyltransferase (HPRT) is mainly known by its role in the metabolism of purines, although impaired expression of this gene is also responsible for causing cell cycle dysregulation and multi-system regulatory dysfunction $(37,38)$. Actin beta $(A C T B)$ is involved in cell structure, motility, and integrity, and, as it is essential to multiple cell functions, the gene is highly abundant in many cell lines (39). Glyceraldehyde 3-phosphate dehydrogenase $(G A P D H)$, although it is reported to be involved in cellular survival, apoptosis and DNA repair, is mainly known to express a cellular energy enzyme determinant to the glycolytic process, functioning as a catalyzer of triose phosphate oxidation and, for this reason, ubiquitously distributed in all cell types $(40,41)$.

As long-established cell lines in literature, mesangial cells and podocytes are important biological samples to determine the best reference gene - many researchers in the field are focused on these structures (42-47) and the data provided by our work could potentially influence many studies, providing support to avoid wrong interpretation of results and its influence in downstream analysis and further conclusions.

\section{CONCLUSION}

We analyzed six different genes using five software applications and the $\Delta \mathrm{Ct}$ method to determine that the best genes to be used for mesangial cell studies with high glucose and angiotensin receptor II blocker are HPRT and $A C T B$, while in the same conditions, the best combination of genes for podocyte gene expression normalization is HPRT together with $G A P D H$. We believe our work may provide support to many research laboratories engaged in mesangial cell and podocytes cell culture studies, allowing them to improve the quality of gene expression studies via qPCR and, consequently, the overall quality of nephrology research.

\section{Funding}

The present study received funding from Fundação de Amparo à Pesquisa do Estado de São Paulo (\#2015/23345-9 - MAB) and Conselho Nacional de Desenvolvimento Científico e Tecnológico (CNPq - NDH).

\section{Author contributions}


bioRxiv preprint doi: https:/doi.org/10.1101/2021.01.19.427251: this version posted January 19,2021 . The copyright holder for this preprint (which was not certified by peer review) is the author/funder, who has granted bioRxiv a license to display the preprint in perpetuity. It is made available under aCC-BY 4.0 International license.

$\mathrm{NDH}, \mathrm{ACA}$, and MAB designed the study. NDH was responsible for cell manipulation. NDH performed the experiments. NDH, ACA, and MAB analyzed the data. NDH, ACA, and MAB wrote the manuscript.

\section{Acknowledgements}

We would like to thank Antonio S. Novaes for cell culture and qPCR technique training.

\section{REFERENCES}

1. Thomas B. The Global Burden of Diabetic Kidney Disease: Time Trends and Gender Gaps. Curr Diab Rep. 2019 Apr;19(4):18.

2. Tuttle KR, Bakris GL, Bilous RW, Chiang JL, Boer IH de, Goldstein-Fuchs J, et al. Diabetic Kidney Disease: A Report From an ADA Consensus Conference. American Journal of Kidney Diseases. 2014 Oct 1;64(4):510-33.

3. Diabetic Kidney Disease | American Society of Nephrology [Internet]. [cited 2019 Aug 28]. Available from: https://cjasn.asnjournals.org/content/12/12/2032.abstract

4. Stitt-Cavanagh E, MacLoed L, Kennedy CRJ. The Podocyte in Diabetic Kidney Disease. The Scientific World JOURNAL. 2009;9:1127-39.

5. Reidy K, Kang HM, Hostetter T, Susztak K. Molecular mechanisms of diabetic kidney disease. J Clin Invest. 2014 Jun 2;124(6):2333-40.

6. Jefferson JA, Shankland SJ, Pichler RH. Proteinuria in diabetic kidney disease: a mechanistic viewpoint. Kidney Int. 2008 Jul;74(1):22-36.

7. Yu SY, Qi R, Zhao H. Losartan reverses glomerular podocytes injury induced by AngII via stabilizing the expression of GLUT1. Mol Biol Rep. 2013 Nov;40(11):6295-301.

8. Derveaux S, Vandesompele J, Hellemans J. How to do successful gene expression analysis using real-time PCR. Methods. 2010 Apr;50(4):227-30.

9. Bustin SA, Benes V, Garson JA, Hellemans J, Huggett J, Kubista M, et al. The MIQE Guidelines: Minimum Information for Publication of Quantitative Real-Time PCR Experiments. Clinical Chemistry. 2009 Apr 1;55(4):611-22.

10. Vandesompele J, De Preter K, Pattyn F, Poppe B, Van Roy N, De Paepe A, et al. Accurate normalization of real-time quantitative RT-PCR data by geometric averaging of multiple internal control genes. Genome Biol. 2002 Jun 18;3(7):RESEARCH0034.

11. Qiu G, Ji Z. AngII-induced glomerular mesangial cell proliferation inhibited by losartan via changes in intracellular calcium ion concentration. Clin Exp Med. 2014 May;14(2):169-76. 
bioRxiv preprint doi: https:/doi.org/10.1101/2021.01.19.427251; this version posted January 19,2021 . The copyright holder for this preprint (which was not certified by peer review) is the author/funder, who has granted bioRxiv a license to display the preprint in perpetuity. It is made available under aCC-BY 4.0 International license.

12. Ren Z, Liang W, Chen C, Yang H, Singhal PC, Ding G. Angiotensin II induces nephrin dephosphorylation and podocyte injury: role of caveolin-1. Cell Signal. 2012 Feb;24(2):443-50.

13. Biederman J, Yee J, Cortes P. Validation of internal control genes for gene expression analysis in diabetic glomerulosclerosis. Kidney Int. 2004 Dec;66(6):2308-14.

14. Andersen CL, Jensen JL, Ørntoft TF. Normalization of real-time quantitative reverse transcription-PCR data: a model-based variance estimation approach to identify genes suited for normalization, applied to bladder and colon cancer data sets. Cancer Res. 2004 Aug 1;64(15):5245-50.

15. Pfaffl MW, Tichopad A, Prgomet C, Neuvians TP. Determination of stable housekeeping genes, differentially regulated target genes and sample integrity: BestKeeper--Excelbased tool using pair-wise correlations. Biotechnol Lett. 2004 Mar;26(6):509-15.

16. Schmittgen TD, Livak KJ. Analyzing real-time PCR data by the comparative C(T) method. Nat Protoc. 2008;3(6):1101-8.

17. Silver N, Best S, Jiang J, Thein S. Selection of housekeeping genes for gene expression studies in human reticulocytes using real-time PCR. BMC Mol Biol. 2006;7(1):33.

18. Leal MF, Astur DC, Debieux P, Arliani GG, Franciozi CES, Loyola LC, et al. Identification of Suitable Reference Genes for Investigating Gene Expression in Anterior Cruciate Ligament Injury by Using Reverse Transcription-Quantitative PCR. Dettman RW, editor. PLoS ONE. 2015 Jul 20;10(7):e0133323.

19. Xie F, Xiao P, Chen D, Xu L, Zhang B. miRDeepFinder: a miRNA analysis tool for deep sequencing of plant small RNAs. Plant Mol Biol. 2012 Jan 31;

20. Hildyard JCW, Finch AM, Wells DJ. Identification of qPCR reference genes suitable for normalizing gene expression in the mdx mouse model of Duchenne muscular dystrophy. PLoS ONE. 2019;14(1):e0211384.

21. DeLorenzo DM, Moon TS. Selection of stable reference genes for RT-qPCR in Rhodococcus opacus PD630. Sci Rep. 2018 16;8(1):6019.

22. da Silva Novaes A, Ribeiro RS, Pereira LG, Borges FT, Boim MA. Intracrine action of angiotensin II in mesangial cells: subcellular distribution of angiotensin II receptor subtypes AT1 and AT2. Mol Cell Biochem. 2018 Nov;448(1-2):265-74.

23. Yano N, Suzuki D, Endoh M, Cao TN, Dahdah JR, Tseng A, et al. High ambient glucose induces angiotensin-independent AT-1 receptor activation, leading to increases in proliferation and extracellular matrix accumulation in MES-13 mesangial cells. Biochem J. 2009 Sep 14;423(1):129-43.

24. He M, Zhang L, Shao Y, Xue H, Zhou L, Wang X-F, et al. Angiotensin II type 2 receptor mediated angiotensin II and high glucose induced decrease in renal prorenin/renin receptor expression. Mol Cell Endocrinol. 2010 Feb 5;315(1-2):188-94. 
bioRxiv preprint doi: https:/doi.org/10.1101/2021.01.19.427251: this version posted January 19,2021 . The copyright holder for this preprint (which was not certified by peer review) is the author/funder, who has granted bioRxiv a license to display the preprint in perpetuity. It is made available under aCC-BY 4.0 International license.

25. Arnoni CP, Maquigussa E, Passos CS, Pereira LG, Boim MA. Inhibition of cellular transdifferentiation by losartan minimizes but does not reverse type 2 diabetes-induced renal fibrosis. J Renin Angiotensin Aldosterone Syst. 2015 Sep;16(3):469-80.

26. Gene Expression Studies: How to Obtain Accurate and Reliable Data by Quantitative Real-Time RT PCR / IZUČAVANJE EKSPRESIJE GENA: KAKO DOBITI TAČNE I POUZDANE PODATKE KVANTITATIVNIM RT PCR-OM U REALNOM VREMENU in: Journal of Medical Biochemistry Volume 32 Issue 4 () [Internet]. [cited 2020 Jan 28]. Available from:

https://content.sciendo.com/view/journals/jomb/32/4/article-p325.xml?lang=en

27. Considerations for Accurate Gene Expression Measurement by Reverse Transcription Quantitative PCR When Analysing Clinical Samples - PubMed [Internet]. [cited 2020 Jan 28]. Available from: https://pubmed.ncbi.nlm.nih.gov/24858468-considerations-foraccurate-gene-expression-measurement-by-reverse-transcription-quantitative-pcr-whenanalysing-clinical-samples/

28. Shao X, Zhang X, Hu J, Gao T, Chen J, Xu C, et al. Dopamine 1 receptor activation protects mouse diabetic podocytes injury via regulating the PKA/NOX-5/p38 MAPK axis. Experimental Cell Research. 2020 Jan 15;111849.

29. Che X, Deng X, Xie K, Wang Q, Yan J, Shao X, et al. Long noncoding RNA MEG3 suppresses podocyte injury in diabetic nephropathy by inactivating $\mathrm{Wnt} / \beta$-catenin signaling. PeerJ [Internet]. 2019 Nov 28 [cited 2020 Jan 21];7. Available from: https://www.ncbi.nlm.nih.gov/pmc/articles/PMC6885352/

30. Liu WJ, Gan Y, Huang WF, Wu H, Zhang X, Zheng HJ, et al. Lysosome restoration to activate podocyte autophagy: a new therapeutic strategy for diabetic kidney disease. Cell Death Dis [Internet]. 2019 Oct 24 [cited 2020 Jan 21];10(11). Available from: https://www.ncbi.nlm.nih.gov/pmc/articles/PMC6813305/

31. Ma J, Zhao N, Du L, Wang Y. Downregulation of lncRNA NEAT1 inhibits mouse mesangial cell proliferation, fibrosis, and inflammation but promotes apoptosis in diabetic nephropathy. Int J Clin Exp Pathol. 2019 Apr 1;12(4):1174-83.

32. Oba S, Ayuzawa N, Nishimoto M, Kawarazaki W, Ueda K, Hirohama D, et al. Aberrant DNA methylation of Tgfb1 in diabetic kidney mesangial cells. Sci Rep [Internet]. 2018 Nov 5 [cited 2021 Jan 12];8. Available from: https://www.ncbi.nlm.nih.gov/pmc/articles/PMC6218490/

33. Randi EB, Vervaet B, Tsachaki M, Porto E, Vermeylen S, Lindenmeyer MT, et al. The anti-oxidative role of cytoglobin in podocytes: implications for a role in chronic kidney disease. Antioxidants \& Redox Signaling [Internet]. 2020 Jan 7 [cited 2020 Jan 21]; Available from: https://www.liebertpub.com/doi/abs/10.1089/ars.2019.7868

34. Chapman JR, Waldenström J. With Reference to Reference Genes: A Systematic Review of Endogenous Controls in Gene Expression Studies. PLOS ONE. 2015 Nov 10;10(11):e0141853. 
bioRxiv preprint doi: https:/doi.org/10.1101/2021.01.19.427251: this version posted January 19,2021 . The copyright holder for this preprint (which was not certified by peer review) is the author/funder, who has granted bioRxiv a license to display the preprint in perpetuity. It is made available under aCC-BY 4.0 International license.

35. Lindström NO, De Sena Brandine G, Ransick A, McMahon AP. Single-Cell RNA Sequencing of the Adult Mouse Kidney: From Molecular Cataloging of Cell Types to Disease-Associated Predictions. Am J Kidney Dis. 2019;73(1):140-2.

36. Park J, Shrestha R, Qiu C, Kondo A, Huang S, Werth M, et al. Single-cell transcriptomics of the mouse kidney reveals potential cellular targets of kidney disease. Science. 2018 May 18;360(6390):758-63.

37. Kang TH, Park Y, Bader JS, Friedmann T. The housekeeping gene hypoxanthine guanine phosphoribosyltransferase (HPRT) regulates multiple developmental and metabolic pathways of murine embryonic stem cell neuronal differentiation. PLoS ONE. 2013;8(10):e74967.

38. Townsend MH, Robison RA, O'Neill KL. A review of HPRT and its emerging role in cancer. Med Oncol. 2018 May 5;35(6):89.

39. Bugyi B, Kellermayer M. The discovery of actin: "to see what everyone else has seen, and to think what nobody has thought"*. J Muscle Res Cell Motil. 2020;41(1):3-9.

40. Hildebrandt T, Knuesting J, Berndt C, Morgan B, Scheibe R. Cytosolic thiol switches regulating basic cellular functions: GAPDH as an information hub? Biol Chem. 2015 May;396(5):523-37.

41. Tossounian M-A, Zhang B, Gout I. The Writers, Readers, and Erasers in Redox Regulation of GAPDH. Antioxidants (Basel) [Internet]. 2020 Dec 16 [cited 2021 Jan 12];9(12). Available from: https://www.ncbi.nlm.nih.gov/pmc/articles/PMC7765867/

42. Takamura S, Fukusumi Y, Zhang Y, Narita I, Kawachi H. Partitioning-Defective-6Ephrin-B1 Interaction Is Regulated by Nephrin-Mediated Signal and Is Crucial in Maintaining Slit Diaphragm of Podocyte. Am J Pathol. 2020 Feb;190(2):333-46.

43. Shi Y, Wang C, Zhou X, Li Y, Ma Y, Zhang R, et al. Downregulation of PTEN promotes podocyte endocytosis of lipids aggravating obesity-related glomerulopathy. Am J Physiol Renal Physiol. 2019 Dec 9;

44. Egerman MA, Campbell KN. Podocyte histone deacetylase activity inhibition as a therapeutic strategy for glomerular disease. Kidney Int. 2019 Dec;96(6):1266-8.

45. Liu B, Lin J, Bai L, Zhou Y, Lu R, Zhang P, et al. Paeoniflorin Inhibits Mesangial Cell Proliferation and Inflammatory Response in Rats With Mesangial Proliferative Glomerulonephritis Through PI3K/AKT/GSK-3 $\beta$ Pathway. Front Pharmacol. 2019;10:978.

46. Yu M, Guan Z, Li S, Wen X, Shi H, Qu G, et al. Gene expression profiling analysis reveals that the long non-coding RNA uc.412 is involved in mesangial cell proliferation. Mol Med Rep. 2019 Dec;20(6):5297-303.

47. Li Y, Zheng L-L, Huang D-G, Cao H, Gao Y-H, Fan Z-C. LNCRNA CDKN2B-AS1 regulates mesangial cell proliferation and extracellular matrix accumulation via miR-4245p/HMGA2 axis. Biomed Pharmacother. 2020 Jan;121:109622. 
Fig. 1. Study workflow. The figure shows the workflow for determination of the most stable reference gene for mesangial cells and podocytes exposed to mannitol, high glucose or high glucose and losartan.

Fig. 2. Melting curves of the primers for the candidate genes. A) ACTB. B) B2M. C) PGAM- 1. D) GAPDH. E) HPRT. F) PPIA.

Fig. 3. Expression profile of the six candidate reference genes in mesangial cells (A) and podocytes (B). A lower threshold value $(\mathrm{Ct})$ represents a higher gene expression level. The data are presented as mean +/- standard deviation. Each dot represents the average from triplicated $\Delta \mathrm{Ct}$ from each sample. All genes were tested for differences among the groups (Kruskal-Wallis test) and all comparisons showed a non-significant result ( $p>0.05)$.

Fig. 4. Evaluation of the optimal number of reference genes in (A) mesangial cells and (B) podocyte cells. Accumulated standard deviation (Acc.SD) was accessed by the GenEx software for the six candidate reference genes in all samples for each cell type. Lower values of Acc.SD indicate the best number of reference genes.

Fig. 5. Correlation between top genes for both cell lines. A) Correlation between $A C T B$ and HPRT expression profile in mesangial cells. B) Correlation between GAPDH and HPRT expression profile in podocytes. $\rho$ : Spearman's rank correlation coefficient. ${ }^{*} \mathrm{p}<0.0001$. 

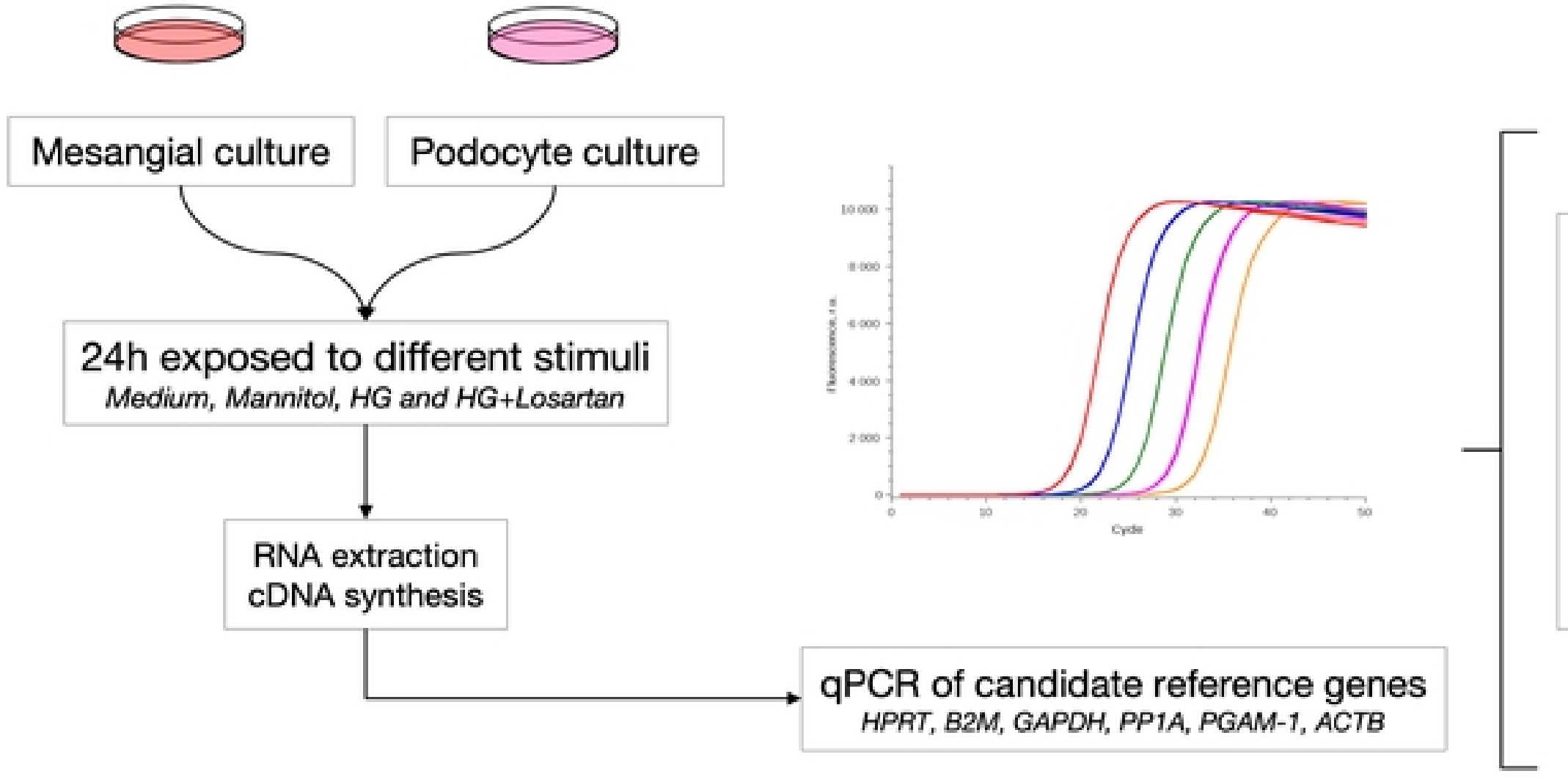

Reference genes stability analysis

- NormFinder

- GeNorm

- Bestkeeper

- DataAssist

- $\Delta$ Ct method

- GenEx

- RefFinder

Figure_1 
A

Melt Curve Plot

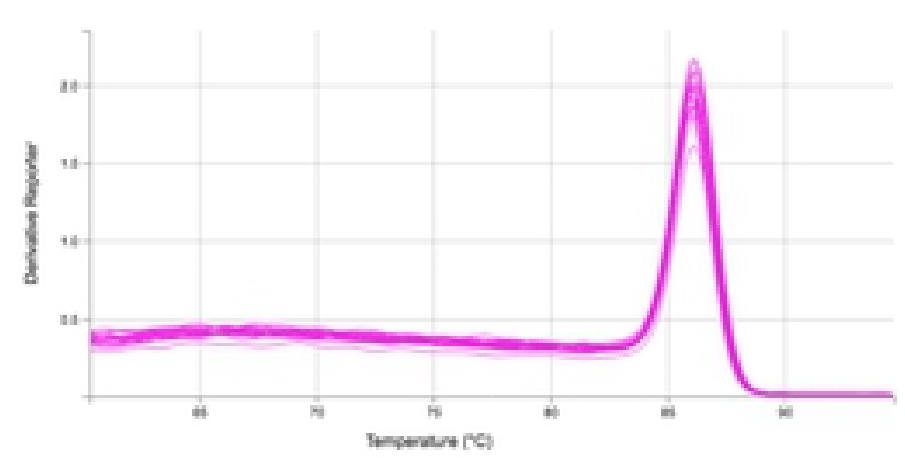

D

Melt Curve Plot

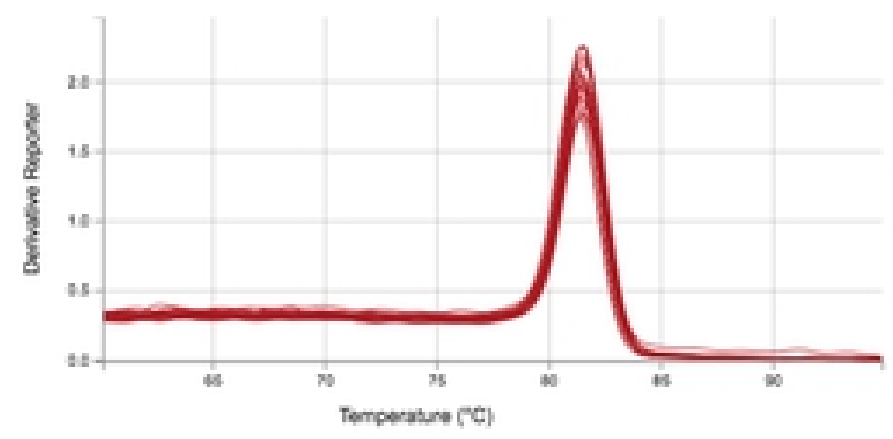

B

Melt Curve Plot

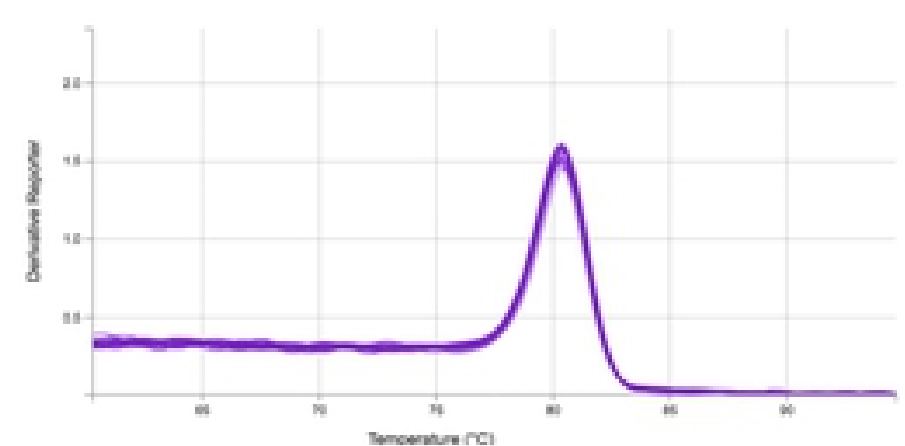

E

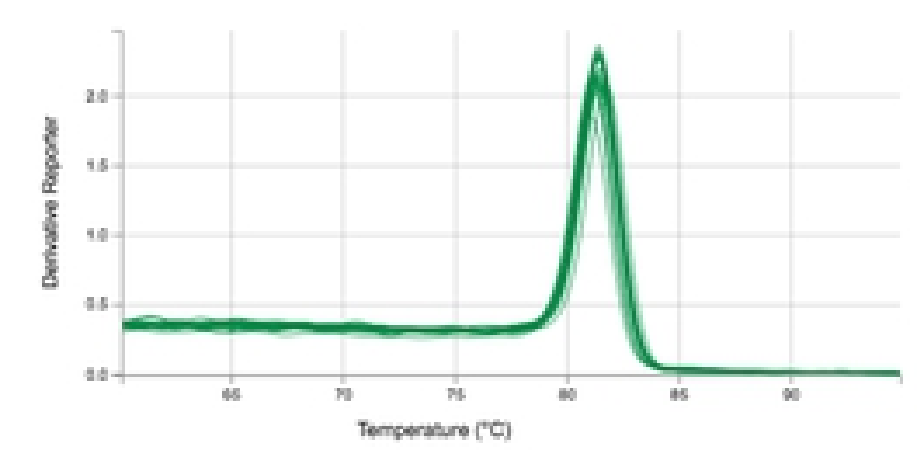

C

Melt Curve Plot

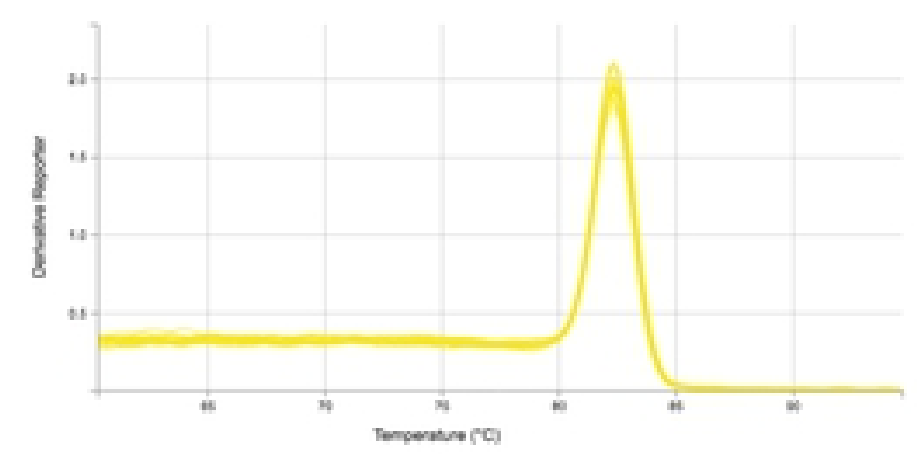

F

Melt Curve Plot

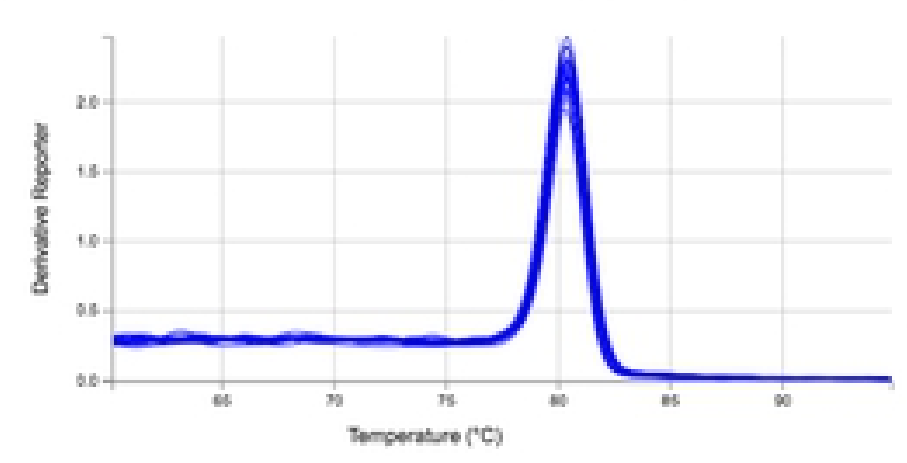

Figure_2 
A

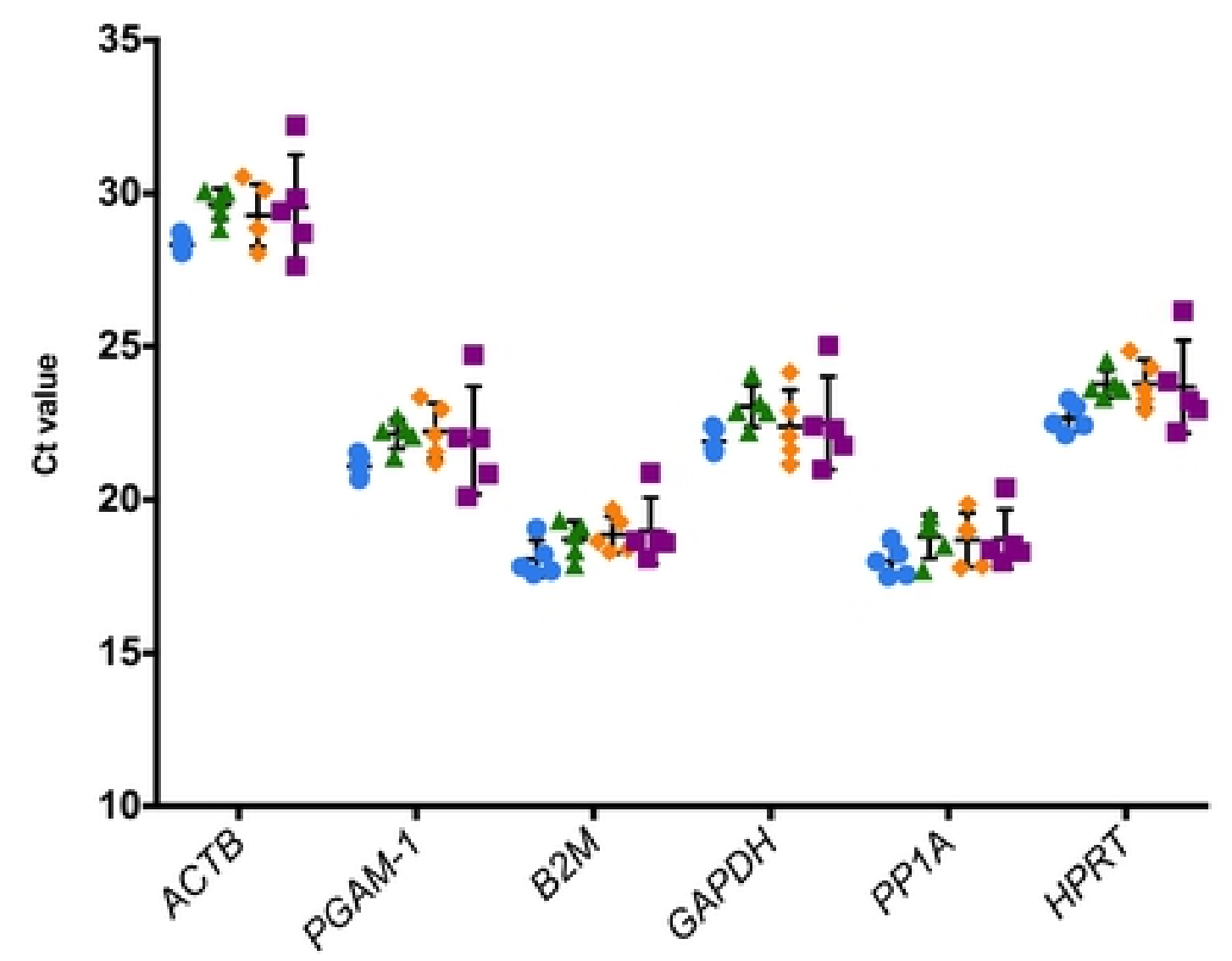

B

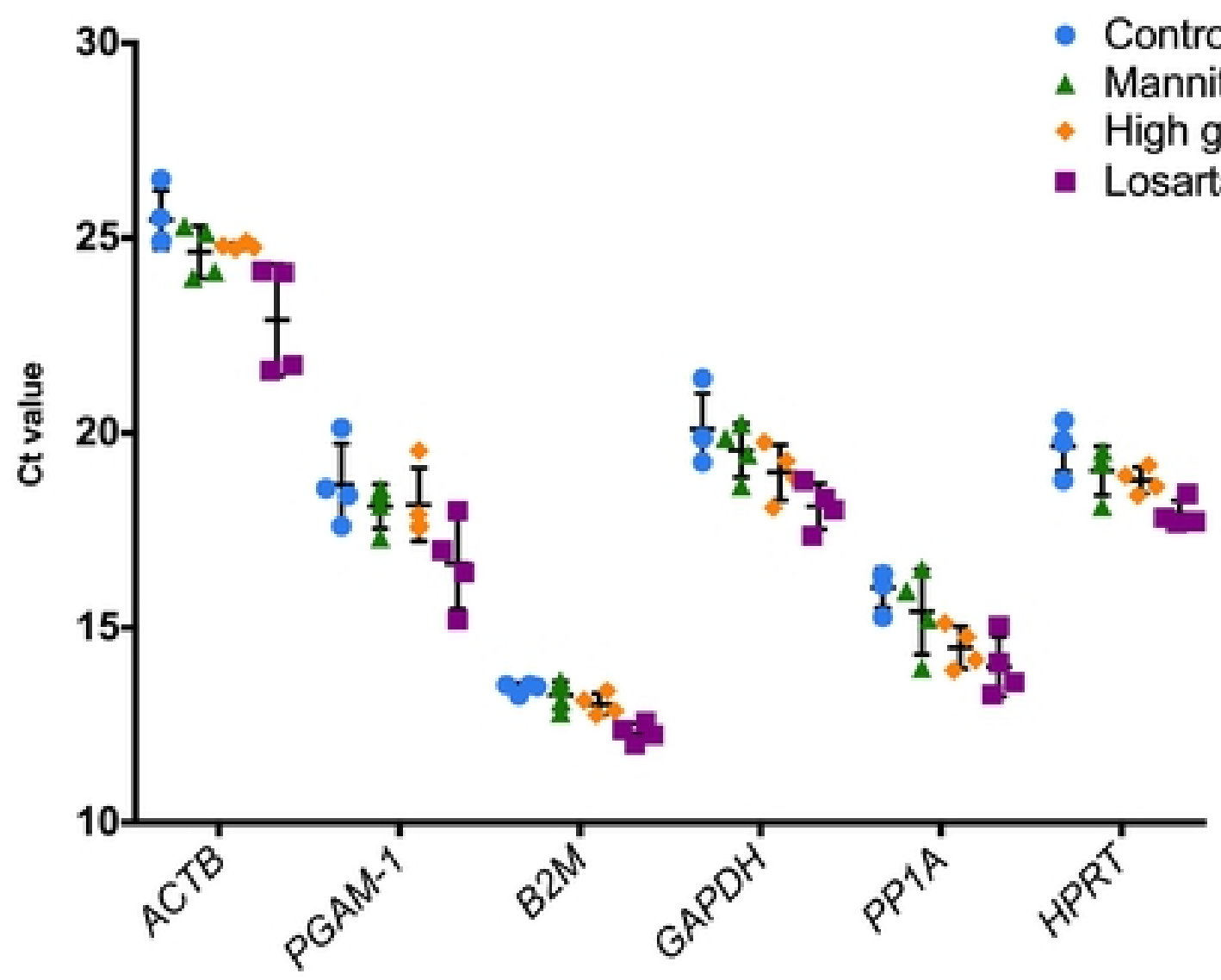

Figure_3 
A

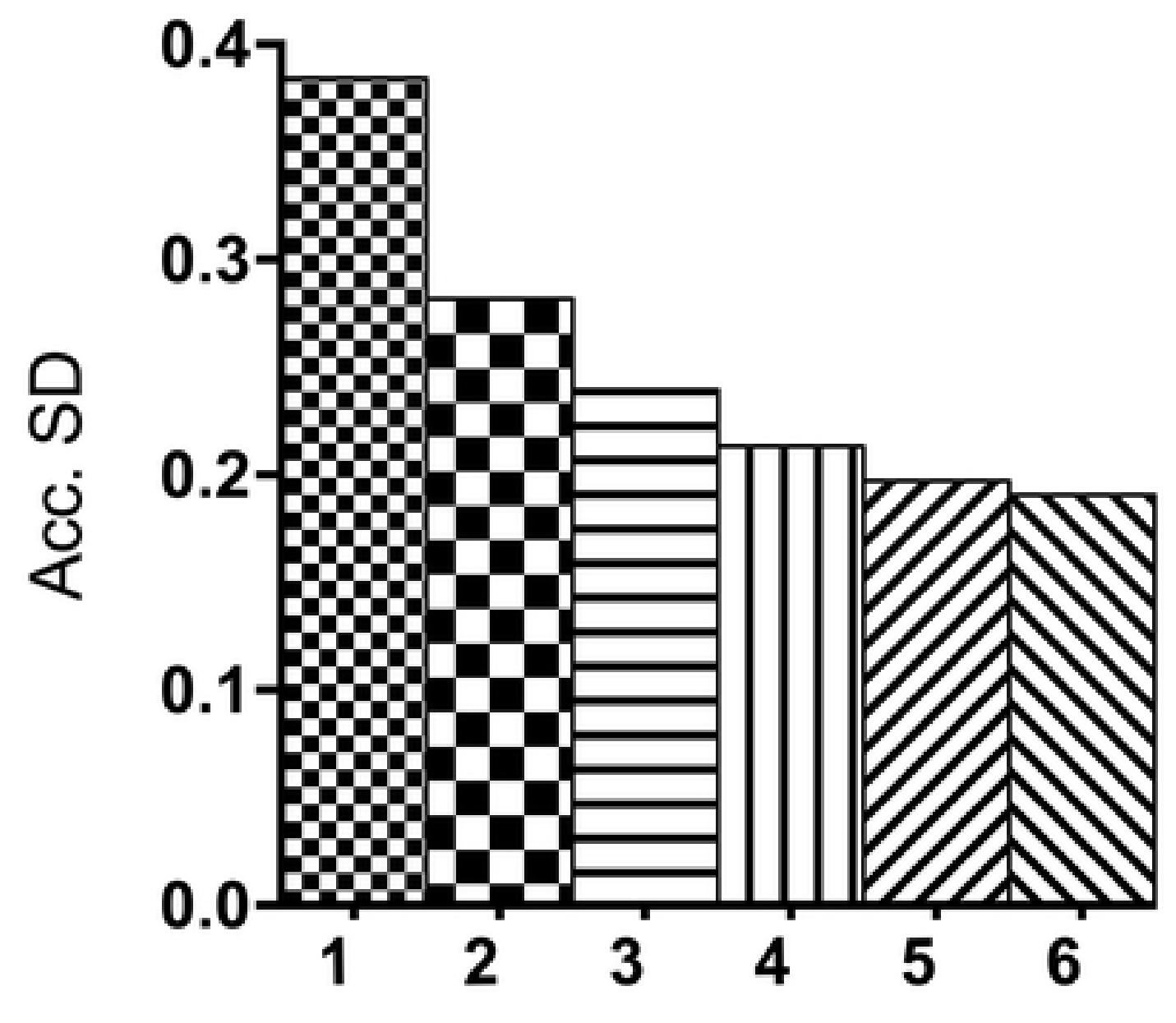

Number of genes
B

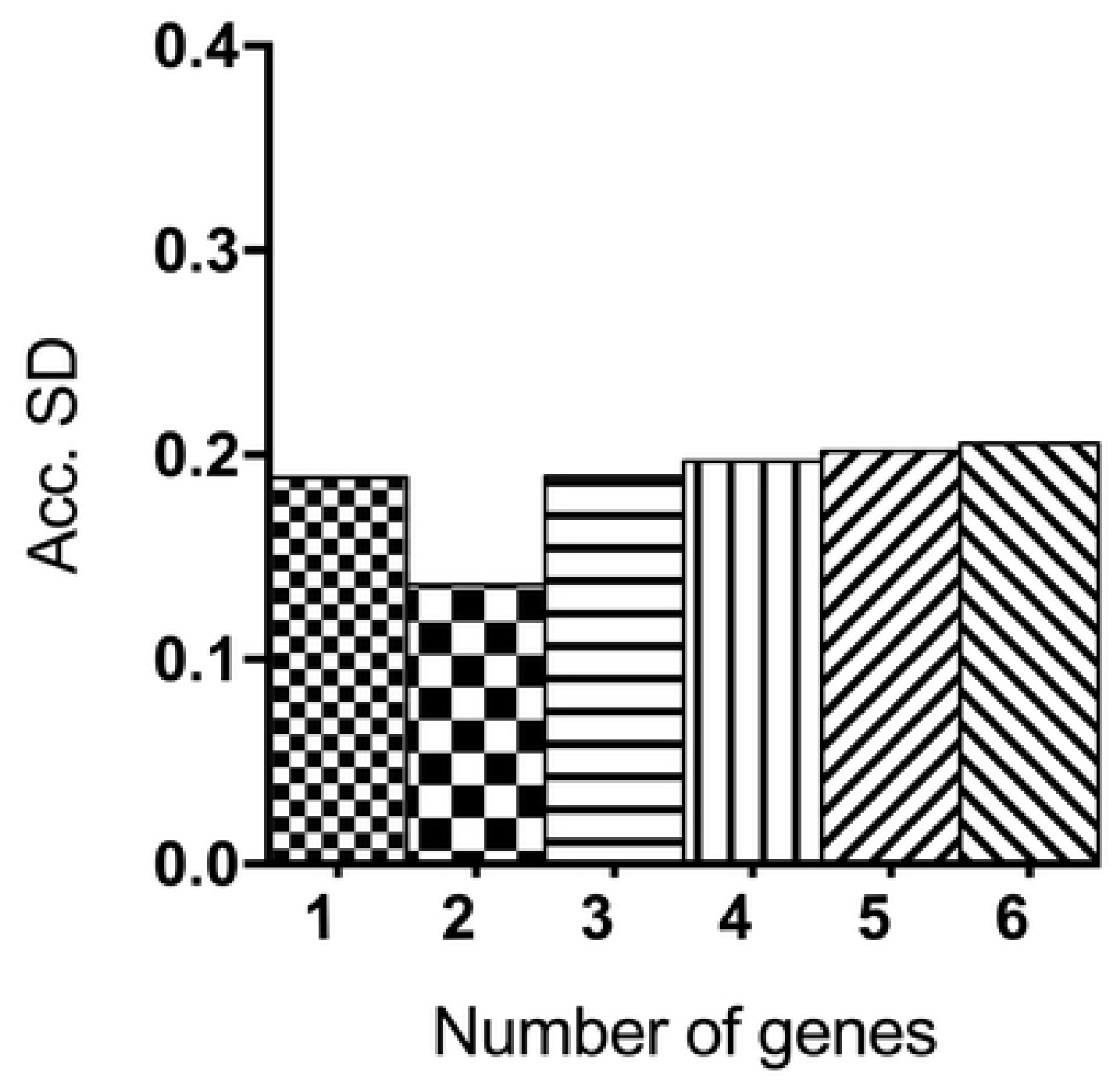

Figure_4 
